Available online on 15.02.2020 at http://jddtonline.info
Open Access to Pharmacentical and Medical Research
unrestricted non-commercial use, provided the original work is properly cited

Open Access

Review Article

\title{
Therapeutic Considerations for Docetaxel and Paclitaxel in Metastatic Breast Cancer
}

\author{
Doranala Harshini ${ }^{*}$, Sreenivas Pasula ${ }^{2 *}$, Vesangi Keerthi Vaishnavi' ${ }^{1}$, Tekula Shiva Sai ${ }^{1}$, M. Rajendar ${ }^{3}$, A. \\ Srinivas Rao ${ }^{3}$, A.V. Kishore Babu ${ }^{1}$
}

1. Pharm D Department of Pharmacy Practice, Bhaskar Pharmacy College, Moinabad, Hyderabad, India

2 Assistant Professor, Department of Pharmacy Practice, Bhaskar Pharmacy College, Moinabad, Hyderabad, India

3. Department of Pharmacology Bhaskar Pharmacy College, Moinabad, Hyderabad, India

\begin{abstract}
Breast cancer is the main source of death among women. Currently, $77 \%$ of women diagnosed with breast cancer are age 50 and older; however, it is projected that approximately $66 \%$ of the new cases diagnosed will occur in women younger than 65 . Taxanes are one of the most effective class of drugs among all the chemotherapeutic agents. They are crucial in the adjuvant therapy of lymph node fantastic or high risk/lymph node poor breast cancer. Several clinical trials have assessed the wellbeing and adequacy of taxanes along with their tolerability in patients with metastatic cancer (MBC) The overview of these Paclitaxel and Docetaxel, the mechanism of action, pharmacokinetics and pharmacodynamics, dose and administration, adverse effects, clinical potency, and sufferable profiles combination therapies, the pathological complete response of these taxanes are included. The different novel formulations of taxanes are formulated from nanoparticles, polyglutamate, liposomes to improve the wellbeing and adequacy taxanes to reduce their toxicities. Single-agent research located with docetaxel and paclitaxel in metastatic breast most cancers show clinically huge antitumor motion even in the advanced stage, heavily pretreated, safe, as properly as in refractory diseases. This action is likewise clear with taxane-based combination regimens. Serious hematologic and nonhematologic toxicities are incompatible, with different toxicities noted dependent on the portion and weekly regimen selected. Weekly docetaxel and paclitaxel regimens speak to important helpful treatment options for women suffering from metastatic breast cancer and have entered assessment as a major aspect of adjuvant treatment for this disease Toxicity associated with taxanes chemotherapy are based totally on the dose schedules and weekly regimen selected and the most frequent toxicities related with these marketers include myalgia, peripheral neuropathy, neutropenia, etc Docetaxel retains in tumor cells for longer duration when compared to paclitaxel because of its slow efflux and large amo unts of uptake into the cell which explains its more benefits when compared to paclitaxel. Clinical studies conducted so far suggested a more benefit to risk ratio for docetaxel when compared to paclitaxel. This article reviews mainly different actions exhibited by taxanes in the therapy of metastatic breast cancer and others on stages of cancer along with the toxicities associated with these agents.
\end{abstract}

Keywords: Metastatic breast cancer, Taxanes, Paclitaxel, Docetaxel, Single-agent, Combination regimen.

Article Info: Received 12 Nov 2019; Review Completed 08 Jan 2020; Accepted 19 Jan 2020; Available online 15 Feb 2020

Cite this article as:

Harshini D, Pasula S, Vaishnavi VK, Shiva Sai T, Rajendar M, Srinivas Rao A, Kishore Babu AV, Therapeutic Considerations for Docetaxel and Paclitaxel in Metastatic Breast Cancer, Journal of Drug Delivery and Therapeutics. 2020; 10(1-s):196204 http://dx.doi.org/10.22270/jddt.v10i1-s.3852

*Address for Correspondence:

Doranala Harshini, Pharm D Department of Pharmacy Practice, Bhaskar Pharmacy College, Moinabad, Hyderabad, India

\section{INTRODUCTION:}

Worldwide, breast cancer is leading cancer in females. Neoadjuvant chemotherapy administered before medical surgery is the possible treatment option for various breast cancer patients [1]. Preoperative chemotherapy diminishes the primary tumor thereby facilitating breast conservation $[2,3]$.

Preoperative chemotherapy administration on open tumors before the medical procedure likewise gives the chance to quickly measure tumor reaction and identify the patients who responded to the therapy. It also helps in attaining pathological complete response (pCR) which is often described by the destruction of all malignant cells from the breast and also from axillary lymph nodes, which is the primary endpoint for disease-free tolerance after neoadjuvant therapy, particularly in triple-negative breast tumor $[4,5]$.

Clinical parameters, for example, estrogen receptornegative status, excessive histological evaluation, and high proliferative fame are associated with excessive affectability to chemotherapy $[5,6]$. Of all the new anti- 
cancer agents developed, the taxanes had a significant effect on wide varieties of malignancies. Paclitaxel ("Figure.1") and docetaxel("Figure.2")

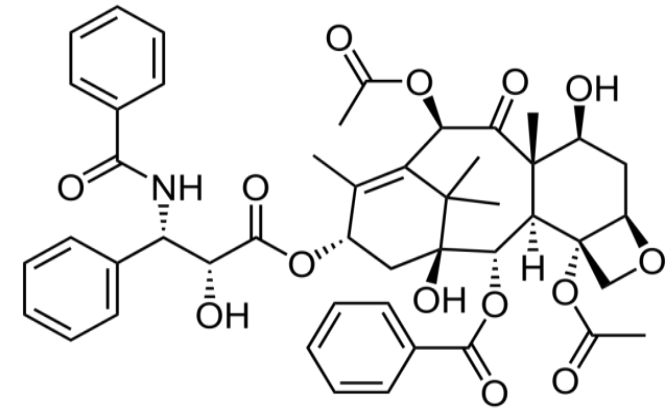

Paclitaxel(figure:1)

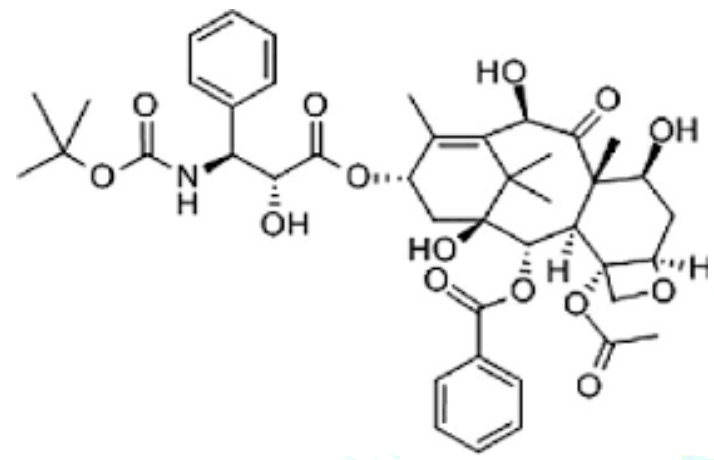

Docetaxel(figure: 2) are treatment options for clinical use approved by the food and drug administration (FDA) board for the therapy of breast malignancy, ovarian disease, non-small cell lung cancer (NSCLC) and prostate cancer growth.

The taxanes are a special type of hydrophobic antineoplastic seller that shows cytotoxic action by way of binding to tubulin and promoting inappropriately stable, non-functional microtubule arrangement [7]. Disruption of the microtubule arrangement leads to telephone death. The toxicity profiles for these retailers are pretty extraordinary; Paclitaxel has adverse effects like peripheral neuropathies and myalgias/arthralgias, though docetaxel most usually associated with fluid retention that might be dose-limiting at some cases [8].

Docetaxel has been known to cause infusion-related responses such as hypersensitivity reactions without premedication; in any case, these responses have happened at a decreased frequency when compared with paclitaxel and can be successfully overseen by premedication with corticosteroids and histamine receptor antagonist [9]. A few procedures are in progress to create alternative formulations of paclitaxel and docetaxel, including the utilization of albumin, nanoparticles, prodrugs, polyglutamate, analogs, emulsions, and liposome, in order to minimize the vehicle-related unfavorable impacts, overcome resistance related to Pglycoprotein and the multi-drug resistant (MDR )gene, and increase reaction rates compared to accomplished with the standard taxanes therapy[10].

Table 1. Drug characteristics of novel taxane formulations

\begin{tabular}{|c|c|c|c|c|c|}
\hline Compound & $\begin{array}{l}\text { Formulation } \\
\text { vehicle }\end{array}$ & $\begin{array}{l}\text { \% parent } \\
\text { compound }\end{array}$ & $\begin{array}{l}\text { Administration } \\
\text { time }\end{array}$ & $\begin{array}{l}\text { Pre medications } \\
\text { required? }\end{array}$ & P-glycoprotein substrate \\
\hline Paclitaxel & Cremophor EL & $100 \%$ & i.v over 1,3 or $24 \mathrm{hr}$ & Yes & Yes \\
\hline Docetaxel & Polysorbate 80 & $100 \%$ & i.v over $1 \mathrm{hr}$ & Yes & Yes \\
\hline Nab paclitaxel & - & $10 \%$ & i.v over $30 \mathrm{~min}$ & No & No data available \\
\hline DHA-paclitaxel & Cremophor EL & $73 \%$ & i.v over $2 \mathrm{hrs}$ & Yes & Yes \\
\hline Paclitaxel poly glumex & - & $37 \%$ & i.v over $10 \mathrm{mins}$ & No & yes \\
\hline BMS- 184476 & Cremophor EL & - & i.v over $1 \mathrm{hr}$ & $\begin{array}{l}\text { Further evaluation } \\
\text { warranted }\end{array}$ & Moderate \\
\hline DJ-927 & - & - & oral( single dose) & No & Poor \\
\hline BMS-275183 & - & - & Oral (single dose) & No & Poor \\
\hline Ortataxel & - & - & $\begin{array}{l}\text { Oral daily for } 5 \\
\text { days }\end{array}$ & No & Poor \\
\hline RPR 109881A & Polysorbate 80 & - & $\begin{array}{l}\text { i.v ranging from 1- } \\
24 \mathrm{hr}\end{array}$ & Yes & Poor \\
\hline $\begin{array}{l}\text { Polymeric-miscellar } \\
\text { paclitaxel }\end{array}$ & Polymeric micelles & $25 \%$ & i.v over $3 \mathrm{hrs}$ & No & Yes \\
\hline $\begin{array}{l}\text { Paclitaxel injectable } \\
\text { depot }\end{array}$ & $\begin{array}{l}\text { ReGel delivery } \\
\text { system }\end{array}$ & $100 \%$ & $\begin{array}{l}\text { Intratumoral } \\
\text { delivery }\end{array}$ & No & - \\
\hline $\begin{array}{l}\text { Liposomal } \\
\text { encapsulated paclitaxel }\end{array}$ & - & $\begin{array}{l}\text { Data } \\
\text { unavailable }\end{array}$ & i.v over $45 \mathrm{mins}$ & $\begin{array}{l}\text { Further evaluation } \\
\text { warranted }\end{array}$ & Yes \\
\hline $\begin{array}{l}\text { Paclitaxel vitamin E } \\
\text { emulsion }\end{array}$ & - & $100 \%$ & i.v over $15 \mathrm{mins}$ & No & $\begin{array}{l}\text { Formulation contains P- } \\
\text { glycoprotein inhibitors }\end{array}$ \\
\hline $\begin{array}{l}\text { Microsphere } \\
\text { encapsulation of } \\
\text { paclitaxel }\end{array}$ & $\begin{array}{l}\text { PACLIMER } \\
\text { delivery system }\end{array}$ & $10 \%$ or $40 \%$ & $\begin{array}{l}\text { Intratumoral } \\
\text { delivery }\end{array}$ & No & - \\
\hline
\end{tabular}




\section{Molecular pharmacology:}

Docetaxel and paclitaxel are diverse in their molecular pharmacology, conceivably clarifying their different activity and toxicity profiles (table 2)

Table 2: mechanistic difference between docetaxel and paclitaxel $[44,45,46]$.

\begin{tabular}{|c|c|c|c|}
\hline Property & Docetaxel & Paclitaxel & Comments \\
\hline High-affinity $\beta$ tubulin-binding & 1.9 & 1.0 & $\begin{array}{l}\text { Higher intracellular drug concentrations are associated with } \\
\text { higher log cell kills and inhibition of tumor growth }\end{array}$ \\
\hline $\begin{array}{l}\text { Drug concentration causing } \\
\text { maximum polymerization }\end{array}$ & $0.2 \mu \mathrm{M}$ & $0.4 \mu \mathrm{M}$ & $\begin{array}{l}\text { Docetaxel is as twice potent as paclitaxel in inhibiting microtubule } \\
\text { depolymerization. }\end{array}$ \\
\hline Cell cycle specificity(phase) & $\begin{array}{l}\text { centrosome } \\
\text { organisation }\end{array}$ & mitotic spindle & $\begin{array}{l}\text { Docetaxel affects centrosome organization in the S-phase resulting } \\
\text { in incomplete mitosis and cell death; It is only partially toxic } \\
\text { against cells in the mitosis and has minimal toxicity against cells in } \\
\text { G1, leading to an accumulation of cells in the G2/M phase; This } \\
\text { differs from paclitaxel, which causes cell damage by affecting the } \\
\text { mitotic spindle. }\end{array}$ \\
\hline
\end{tabular}

Docetaxel shows a greater affinity to ß-tubulin, focusing on centrosome organization and shows its effects three different stages of cell cycle $(\mathrm{S} / \mathrm{G} 2 / \mathrm{M})$, while paclitaxel causes cell damage by disrupting the mitotic spindle in the G2 and M stages of cycle [ 44]. Docetaxel is a cell cyclespecific targeted therapy which acts on S-phase, while the most extreme resistance to $S$-phase is found with paclitaxel [45].

An additional difference between the taxanes incorporates greater take-up of docetaxel into tumor cells and more slow efflux of docetaxel from tumor cells, accordingly prompting longer maintenance times, giving a potential clarification to the inadequate cross-resistance between the drugs [46].

\section{PHARMACOKINETICS AND PHARMACODYNAMICS:}

There are generous differences in the pharmacokinetic and pharmacodynamic profiles of docetaxel and paclitaxel, an issue that may add to the troubles is with characterizing the ideal plan for paclitaxel monotherapy and combination regimens, especially with anthracyclines.

Both taxanes are broadly metabolized in the liver by the cytochrome P-450 compounds and experience biliary excretion as their primary source of elimination, in this way bringing about the requirement for dose reductions in patients with raised liver enzymes. A significant division of the taxane portion is discharged in feces as parent drug or hydroxylated metabolites; the familiar metabolites of both taxanes are either inert or less intense than the parent compound. The both taxanes have broadly distribution of tissue, profoundly protein-bound, and roughly $6 \%$ of either medication are renally eliminated [47],

\section{Weekly Docetaxel administration in MBC}

\section{Weekly Single-Agent Docetaxel}

Weekly Docetaxel administration in MBC Weekly SingleAgent Docetaxel Weekly management of docetaxel has been assessed in phase II trials of women with MBC (Table 3) [11-23]. the bulk of patients in those examinations had arranged earlier chemotherapy for MBC and most had an Eastern Cooperative Oncology Group (ECOG) performance status score of 0 or 1 .

Stemmler et al. [34] detailed median times to progression (TTPs) of 6.6 months in chemotherapy-credulous patients and 5.9 months in pretreated patients; in like manner, Aihara et al. [20] and Kim et al. [12] announced a median TTP of 5 months. In patients resistant to anthracyclines, Ramos et al. [14] announced 8.4

months as the median time to illness progression. The medial overall endurance in these trails went from 13-14 months [14, 19-21]. Weekly docetaxel regimens were very much tolerated, and grade 4 toxicities were uncommon. The most well-known 3 toxicities associated with docetaxel include neutropenia, frailty, and fatigue/asthenia; Ocular toxicity is generally presented as increased lacrimation. This increased lacrimation is due to canalicular stenosis [22] and also nail toxicities were likewise prominent. Stemmler et al. randomized patients to get either dexamethasone (Decadron $\AA$; Merck and Co., Inc., Whitehouse Station, NJ, http://www.merck.com) premedication or no premedication; patients who got dexamethasone had a fundamentally lower frequency of nail changes these investigations show that week by week docetaxel administration $\mathrm{l}$ at portions of $35-40 \mathrm{mg} / \mathrm{m} 2$ has clinical action in MBC, creating reactions in $30 \%-40 \%$ of pretreated patients, with a median TTP of around 7 months. This schedule is related with a low rate of the classic grade 3-4 hematologic and nonhematologic toxicities reported with every 3-week regular intervals plans. 
Table 3: Chosen stage II investigations of weekly single-agent docetaxel in metastatic breast cancer (MBC)

\begin{tabular}{|c|c|c|c|c|c|}
\hline Study & $\begin{array}{l}\text { Patient } \\
\text { characters ( } \% \\
\text { of subjects) }\end{array}$ & $\begin{array}{l}\text { Treatment } \\
\text { regimen }\end{array}$ & $\begin{array}{l}\text { No.of } \\
\text { evaluable } \\
\text { patients }\end{array}$ & ORR(CR) & $\begin{array}{l}\text { Grade } \geq 3 \text { toxicity in } \geq 5 \% \text { of } \\
\text { patients ( } \% \text { of patients) }\end{array}$ \\
\hline $\begin{array}{l}\text { Burstein et } \\
\text { al[18]. }\end{array}$ & \begin{tabular}{lr}
\multicolumn{3}{l}{ Previously } \\
treated & MBC \\
$(66 \%) ; \quad$ ECOG \\
PS score & $0-1$ \\
$(97 \%) ;$ & ER \\
positive & \\
$(65 \%) ; \quad \geq 3$ \\
metastatic \\
sites (65\%)
\end{tabular} & $\begin{array}{l}\text { Docetaxel, } 40 \\
\mathrm{mg} / \mathrm{m} 2 \times \text { i.v. } \\
\text { weekly } \times \quad 6 \\
\text { weeks follow } \\
\text { by } 2 \text {-week rest }\end{array}$ & 29 & $41 \%(0)$ & $\begin{array}{l}\text { Neutropenia (14\%), fatigue/ asthenia } \\
(14 \%)\end{array}$ \\
\hline $\begin{array}{l}\text { Stemmler et al. } \\
\text { [19] }\end{array}$ & $\begin{array}{l}\text { Previously } \\
\text { treated MBC } \\
(85 \%) ; \quad \text { ECOG } \\
\text { PS score } \leq 2\end{array}$ & $\begin{array}{l}\text { Docetaxel, } 35 \\
\text { mg/m2 i.v. } \\
\text { weekly } \times 6 \\
\text { weeks follow } \\
\text { by 2-week rest; } \\
\text { then } \\
\text { docetaxel,35 } \\
\text { mg/m2 i.v. } \\
\text { weekly } \quad 3 \\
\text { weeks follow } \\
\text { by 2-week rest }\end{array}$ & 100 & $42 \%(10 \%)$ & $\begin{array}{l}\text { Neutropenia ( } 1 \% \text { of cycles), anemia }(6 \% \\
\text { of cycles), alopecia }(25 \%) \text {, asthenia } \\
(6 \%) \text {, pain }(7 \%)\end{array}$ \\
\hline Aihara et al. [20] & $\begin{array}{l}\text { Previously } \\
\text { treated MBC } \\
(25 \%) \text { median } \\
\text { age, } 74 \text { years } \\
\text { (range, 50- } \\
\text { 88); ECOG PS } \\
\text { score } 0-1 \\
\begin{array}{l}\text { (78\%); ER - } \\
\text { positive (56\%) }\end{array}\end{array}$ & $\begin{array}{l}\text { Docetaxel, } 40 \\
\text { mg/m2 i.v. } \\
\text { weekly } \times 3 \\
\text { weeks; cycles } \\
\text { repeated every } \\
4 \text { weeks }\end{array}$ & 37 & $38 \%(0)$ & Neutropenia (19\%) \\
\hline $\begin{array}{l}\text { Hainsworth et } \\
\text { al. [21] }\end{array}$ & $\begin{array}{l}\text { Previously } \\
\text { treated MBC } \\
(25 \%) \text {; median } \\
\text { age, } 74 \text { years } \\
\text { (range, 50- } \\
\text { 88); ECOG PS } \\
\text { score } 0-1 \\
\begin{array}{l}\text { (78\%); ER - } \\
\text { positive (56\%) }\end{array}\end{array}$ & $\begin{array}{l}\text { Docetaxel,36 } \\
\text { mg/m2 i.v. } \\
\text { weekly } \times 6 \\
\text { weeks, } \\
\text { followed by } 2- \\
\text { week rest }\end{array}$ & 36 & $36 \%(3 \%)$ & $\begin{array}{l}\text { Leukopenia }(5 \%), \text { anemia }(5 \%) \text {, } \\
\text { fatigue/asthenia }(20 \%) \text {, diarrhea }(10 \%) \text {, } \\
\text { nausea/vomiting }(7 \%), \text { peripheral } \\
\text { edema }(7 \%)\end{array}$ \\
\hline $\begin{array}{l}\text { Estevez et al. } \\
\text { [22] }\end{array}$ & $\begin{array}{l}\text { formerly } \\
\text { untreated } \\
\text { LABC; median } \\
\text { age, 53 years } \\
\text { (range, 28- } \\
\text { 73); ECOG PS } \\
\text { score } 0 \text { (98\%); } \\
\text { stage II, 87\%; } \\
\text { stage III 13\% } \\
\text { seriously } \\
\text { pretreated } \\
\text { MBC; weak or } \\
\text { elderly } \\
\text { patients (over } \\
70 \text { years of } \\
\text { age); norm age, }\end{array}$ & $\begin{array}{l}\text { Docetaxel, } 40 \\
\text { mg/m2 i.v. } \\
\text { weekly for the } \\
\text { first } 6 \text { weeks of } \\
\text { an } \quad \text {-week } \\
\text { cycle for } 2 \\
\text { cycle }\end{array}$ & 56 & $\begin{array}{l}68 \%(16 \% \mathrm{pCR} \\
\text { rate) }\end{array}$ & $\begin{array}{l}\text { Neutropenia, asthenia }(16 \%) \text {, nail } \\
\text { disorders }(16 \%) \text {, cutaneous toxicity } \\
(14 \%)\end{array}$ \\
\hline
\end{tabular}




\begin{tabular}{|c|c|c|}
\hline $\begin{array}{l}\text { D'Hondt et al. } \\
\text { [23] }\end{array}$ & $\begin{array}{l}63 \quad \begin{array}{r}\text { years } \\
\text { (range, } 43-\end{array} \\
82) ; \text { ECOG PS } \\
\text { score } 1(34 \%) \text {, } \\
2(55 \%) \text {, and } 3 \\
(9 \%) ; \quad \text { ER- } \\
\text { positive, } 62\end{array}$ & $\begin{array}{l}\text { initial } 6 \text { weeks, } \\
\text { follow by } 1 \text { - } \\
\text { week rest }\end{array}$ \\
\hline & $\begin{array}{l}\text { Anthracycline } \\
\text { expose } \\
\text { MBC:Second } \\
\text { line } \\
\text { management } \\
\text { (54\%)norm } \\
\text { age 53 } \\
\text { years(34-74) } \\
\text { Anthracycline } \\
\text {-resistant } \\
\text { LABC/MBC }\end{array}$ & $\begin{array}{l}\text { Docetaxel,35 } \\
\mathrm{mg} / \mathrm{m} 2 \text { once } \\
\text { weekly } \times 6 \\
\text { weeks, follow } \\
\text { by 2-week rest }\end{array}$ \\
\hline
\end{tabular}

Ford et al. [13]

Ramos et al.

[14]

Jackisch et al.

[11]
Docetaxel,40 $\mathrm{mg} / \mathrm{m} 2$ for 6 successive weeks, follow by 2 -week rest in first 18 patients; reduced to 36 $\mathrm{mg} / \mathrm{m} 2$ for the

Pretreated next 17 patient.

Docetaxel,40 breast cancer; Japanese patients

Pretreated MBC $(100 \%)$; second-line treatment (98.1\%); norm age 58 years (range, 3180); Karnofsky performance status $\quad 60 \%-$ $100 \%$
Fatigue(16\%)

stomatitis $7 \%$, diarrhea $14 \%$, cutaneous toxicity 19

neutropenia(17\%),asthenia, nail, visual, and cutaneous disorders

Neutropenia(16.2\%)

dysgeusia (18.9\%), dacryorrhea (16.2\%), acoustic disturbance $(16.2 \%$

neutropenia(3.5\%)

alopecia(14.3\%)

Abbreviations: CR- complete response; ECOG- Eastern Cooperative Oncology Group; ER-estrogen receptor; LABC-locally advanced breast cancer; NR- not reported; ORR- overall response rate; pCR- pathologic complete response; PS- performance status. 


\section{Harshini et al}

\section{Weekly Docetaxel-Based Combination Regimens in $\mathrm{MBC}$}

The promising results of studies studies assessing weekly docetaxel because every single agent gives the basis for evaluating weekly docetaxel in combination chemotherapy regimens for MBC. phase I and stage II trials have evaluated weekly docetaxel regimens combination with anthracyclines [24-27], gemcitabine [28-32], vinorelbine [29, 33], and trastuzumab [34]

The combination of two inhibitors of microtubule function, docetaxel, and estramustine demonstrated to be too toxic to even think about being researched further [35]. These investigations demonstrate that weekly docetaxel in combination with anthracycline, gemcitabine, or vinorelbine is achievable. The activity in both recently treat and untreated patients ith MBC is great (up to 85\%$90 \%$ in untreated patients $[24,25]$.

However, this degree of activity is accomplished at the expense of higher lethality, with higher rates of neutropenia, febrile neutropenia, asthenia, and alopecia. These combination regimens may comprise a possibility for young, fit patients giving an extensive, hazardous disease, for whom a quick and significant tumor volume decrease is required.

\section{Docetaxel-Trastuzumab Combinations}

Docetaxel-trastuzumab combination is incredibly dynamic when utilized as a weekly treatment in HER-2positive patients, with reaction rates in the range of 55\%$75 \%$, even in pretreated patients.

The toxicity quality profile is entirely good, with the evaluation of grade 3-4 toxicities, supporting the
Journal of Drug Delivery \& Therapeutics. 2020; 10(1-s):196-204

utilization of this regimen as a forefront treatment for this patient population [43].

\section{Week by week Paclitaxel in MBC}

\section{Weekly Single-Agent Paclitaxel}

Like docetaxel, paclitaxel given on a weekly plan has been considered broadly both being a single agent also in blend chemotherapy. Common toxicities related to the regular intervals of paclitaxel dosing are neutropenia, neuropathy, and arthralgia/myalgia. Week by week dosing of paclitaxel has been evaluated as a way to improve dose quantity and enhance tolerability.A several phases II studies have assessed weekly paclitaxel dosing as a single-agent treatment in subjects with MBC (Table 4).

Seidman and partners assessed constant paclitaxel treatment, $100 \mathrm{mg} / \mathrm{m} 2$ every week, in 30 women with MBC who had gotten earlier adjuvant or potentially metastatic treatment (Table 3) [36]. Three patients in that review accomplished complete response $(10 \%)$ and 16 accomplished partial response (43\%) for an ORR of 53\% (95\% CI, 34\%-72\%). Treatment was commonly very much tolerated.

Evaluation 3-4 neutropenia happened in four patients, without any episodes of febrile neutropenia. There was no proof of cumulative neutropenia and no cases of thrombocytopenia. The main incessant evaluation 3 nonhematologic harmfulness was neurosensory toxicity in seven patients $(24 \%)$, five of whom had gotten paclitaxel dosages of $110-120 \mathrm{mg} / \mathrm{m} 2$ [36]. A phase II analysis gave a statement of the utilization of weekly paclitaxel $(100$ $\mathrm{mg} / \mathrm{m} 2$ ) administrated as first-line chemotherapy for MBC [37].

Table 4. chosen phase II/III study of weekly single-agent paclitaxel during metastatic breast cancer (MBC)

\begin{tabular}{|c|c|c|c|c|c|}
\hline Study/phase & $\begin{array}{l}\text { Patient } \\
\text { characteristics(\% of } \\
\text { patients) }\end{array}$ & $\begin{array}{l}\text { Treatment } \\
\text { regimens }\end{array}$ & $\begin{array}{l}\text { No. of } \\
\text { evaluab } \\
\text { le } \\
\text { patients }\end{array}$ & ORR(CR) & $\begin{array}{l}\text { Grade } \geq 3 \text { toxicity in } \geq 5 \% \text { of } \\
\text { patients }(\% \text { of patients }\end{array}$ \\
\hline Seidman[37] & 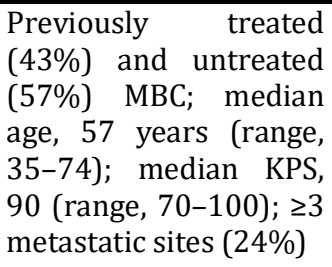 & $\begin{array}{lr}\text { Paclitaxel, } & 100 \\
\mathrm{mg} / \mathrm{m} 2 & \text { i.v. } \\
\text { weekly until } & \text { development }\end{array}$ & 30 & $53 \%(10 \%)$ & $\begin{array}{ll}\text { Leukopenia } & (17 \%), \\
\text { neutropenia } & (14 \%), \\
\text { neurosensory } & (24 \%), \\
\text { hyperglycemia (7\%) } & \end{array}$ \\
\hline $\begin{array}{l}\text { Wist et al. [37] } \\
\text { Phase II }\end{array}$ & $\begin{array}{l}\text { Previously untreated } \\
\text { MBC; norm age, } 53 \\
\text { (range, 33-68); prior } \\
\text { adjuvant CT }(60 \%) \text {; no } \\
\text { Prior CT for MBC; } \geq 2 \\
\text { metastatic site }(49 \%)\end{array}$ & $\begin{array}{lr}\text { Paclitaxel, } & 100 \\
\mathrm{mg} / \mathrm{m} 2 & \text { i.v. } \\
\text { weekly until } \\
\text { development }\end{array}$ & 33 & $40 \%(3 \%)$ & $\begin{array}{l}\text { Neutropenia } \\
\text { neurotoxicity }(14 \%)\end{array}$ \\
\hline $\begin{array}{l}\text { Akerley et al[39]. } \\
\text { Phase II }\end{array}$ & $\begin{array}{l}\text { Previously untreated } \\
\text { MBC or unresectable } \\
\text { LABC; median age, } 58 \\
\text { years }\end{array}$ & $\begin{array}{lr}\text { Paclitaxel, } & 175 \\
\mathrm{mg} / \mathrm{m} 2 & \text { i.v. } \\
\text { weekly } \times 6 \\
\text { weeks } & \text { followed } \\
\text { by } \quad \text {-week } \\
\text { break; cycles } \\
\text { recurring until }\end{array}$ & $\begin{array}{l}\text { MBC: } 18 \\
\text { LABC: } \\
14\end{array}$ & $\begin{array}{l}78 \%(11 \%) 78 \% \\
(21 \%\end{array}$ & $\begin{array}{l}\text { Neutropenia(65\%)grade } \\
2-3 \text { myalgia }(25 \%) \text {, grade } 2-3 \\
\text { hyperglycemia }(19 \%) \text {, grade } \\
2-3 \text { rash }(16 \%) \text {, grade } 2-3 \\
\text { mucositis }(16 \%), \text { grade } 2-3 \\
\text { nausea }(13 \%), \text { grade } 2-3\end{array}$ \\
\hline
\end{tabular}


Perez et al. [40] Phase II

ten Tije et al.[41]

Phase II
Previously treated (69\%) and untreated (31\%) MBC; mean age, 60 years (range, 3188); ECOG PS score $0-1$ $(88 \%) ; \geq 3$ metastatic sites (46\%); prior anthracyclines (72\%); former taxanes (25\%)

Hormone-refractory elderly (>70 years) MBC; median age, 77 (range, 71-84); prior adjuvant CT (5\%); no Prior CT for $\mathrm{MBC}$; $\geq 3$ metastatic sites (50\%)

Sikov et al. [42] Phase III

Lombardi et al. [38]
Paclitaxel, $\quad 80$ $\mathrm{mg} / \mathrm{m} 2$ weekly weeks; cycles repeated until PD or excessive toxicity

$\mathrm{mg} / \mathrm{m} 2$

administer

weekly on days

1,8 , and 15 of a

28-day cycle
$22 \%$

$$
\begin{aligned}
& \text { Paclitaxel, } 150 \\
& \mathrm{mg} / \mathrm{m} 2 \quad \text { i.v. } \\
& \text { weekly } \times \quad 6 \\
& \text { weeks followed } \\
& \text { by 2-week rest; } \\
& \text { cycles repetitive } \\
& \text { every } 8 \text { weeks } \times \\
& 2
\end{aligned}
$$

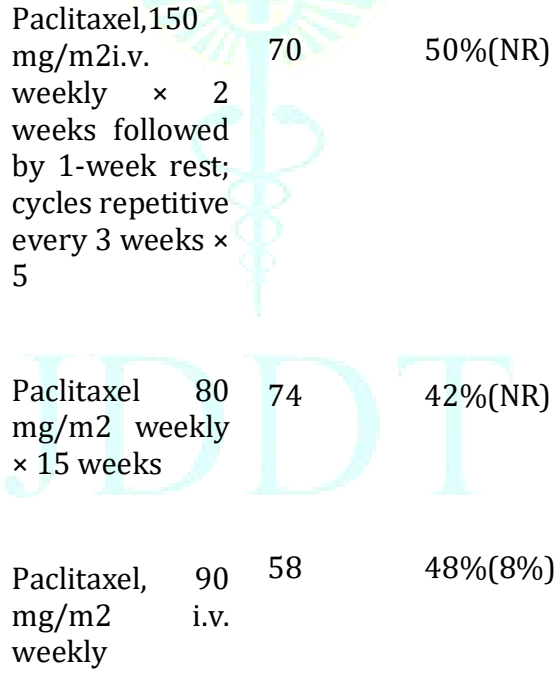

Neutropenia(15\%),anemia(9 $\%)$, neuropathy (9\%)

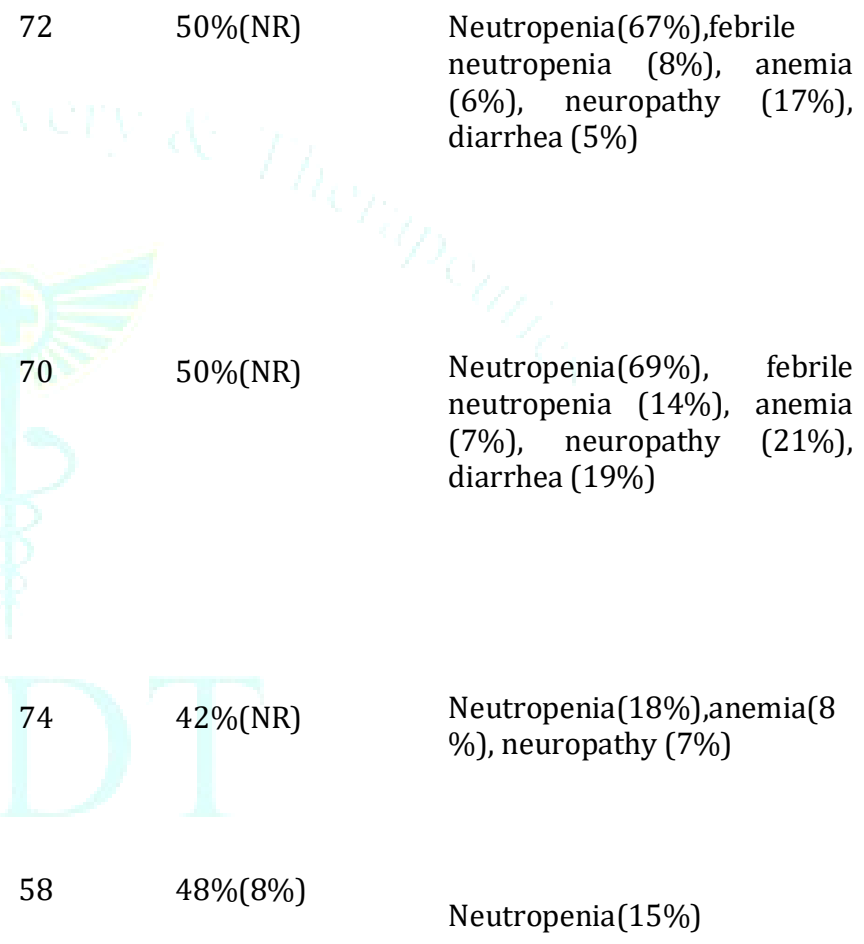
neutropenia (8\%), anemia $(6 \%)$, neuropathy (17\%), diarrhea (5\%)

Neutropenia(69\%), febrile neutropenia (14\%), anemia (7\%), neuropathy (21\%), diarrhea (19\%)

Neutropenia(18\%),anemia(8 $\%)$, neuropathy (7\%)

Neutropenia(15\%)

Neutropenia(12\%), anemia(12\%), neuropathy $(4 \%$

a Paclitaxel doses could be increased or decreased at $10-\mathrm{mg} / \mathrm{m} 2$ increment after 4 weeks, then every 2 weeks.

Abbreviations: CR-complete response; CT- chemotherapy; ECOG- Eastern Cooperative Oncology Group; KPS,-Karnofsky performance status; LABC- locally advanced breast cancer; NR- not reported; ORR- overall response rate; PD- progressive disease; PS- performance status

\section{Weekly Paclitaxel-Based Combination Regimens in MBC:}

Evaluating weekly paclitaxel in MBC present the basis for evaluating the therapy method for combination regimens. Weekly paclitaxel has been examined in combination with anthracyclines, platinum specialists, and trastuzumab.

collectively, these examinations demonstrated that paclitaxel in blending by anthracyclines or platinum can accomplish reaction rates from $42 \%$ up to $82 \%$, with a median TTP of a while. The most regular evaluation 3-4 toxicities recorded were neutropenia, alopecia, and neuropathy. These underlying phase I/II think about demonstrated the attainability of the various schedules to be additionally assessed in randomized stage III trails.

\section{Weekly Paclitaxel-Trastuzumab Combinations.}

Paclitaxel in sequence with trastuzumab is highly active regimen that can shorten neoplasms in $56 \%-86 \%$ of the HER-2-positive breast cancer patients, beside a low frequency of evaluation 3-4 toxicities. It gives a reliable and efficient treatment that can give 8-12months progression-free durability for the subgroup of patients overexpressing HER-2[43]. 


\section{TOXICITIES OF THE TAXANES}

The different taxanes are likewise clear in their antagonistic impact profiles. Paclitaxel is related to anaphylaxis and severe hypersensitivity responses followed by hypotension, dyspnea, angioedema, and generalized urticaria. Different replies normally more recognized by paclitaxel than docetaxel include myalgias and neuropathy. Every symptom profile of docetaxel gives off the impression of being scheduled dependent.

When given at regular intervals, docetaxel is all the more as often as possible related to reversible, noncumulative neutropenia, fluid retention, cutaneous responses, and hyperlacrimation (Table 3). Be that as it may, when directed utilizing a week by week dosing plan, the toxicity profile of docetaxel is extraordinary and incorporates less hematologic toxicities, less stomatitis, less cutaneous occasions, and less neurologic toxicities, however a more noteworthy measure of evaluation $3 / 4$ exhaustion/asthenia [48]. Reactions regular to the both methods for administration include hyperlacrimation and fluid retention. Reactions regular to the both methods for administration include hyperlacrimation and fluid retention. Less acute toxicity has associated with related to weekly docetaxel treatment than with each 3-week docetaxel treatment.

Table 5: management of Docetaxel-specific toxicities [48]

\begin{tabular}{|l|l|}
\hline ADVERSE REACTION & MANAGEMENT \\
\hline $\begin{array}{l}\text { Fluid retention : weight gain and peripheral edema compared } \\
\text { to total dose(5th-7th cycle) }\end{array}$ & 2-3 days of steroid treatment responding to diuretics. \\
\hline $\begin{array}{l}\text { Skin and nail disorders } \\
\text { Palmar- Plantar erythrodysesthesia } \\
\text { Onycholysis and soreness(rare) }\end{array}$ & $\begin{array}{l}\text { Healthy skin and nail care. } \\
\text { Cyclo oxygenase-2- inhibitor under study. }\end{array}$ \\
\hline $\begin{array}{l}\text { Hyperlacrimation(epiphora) } \\
\text { Primarily associated with weekly schedule and cumulative } \\
\text { dose above } 300 \mathrm{mg} / \mathrm{m} 2\end{array}$ & $\begin{array}{l}\text { Instillation of artificial tears. } \\
\text { Lacrimal canicular prosthesis. }\end{array}$ \\
\hline
\end{tabular}

\section{Which Is the Preferred Taxane?}

In view of indirect correlations just as the results of the ongoing randomized trials led in patients with $\mathrm{MBC}$, docetaxel by all accounts seems to be the more active taxane . In addition to its more extended half-life, docetaxel has an increasingly quick cell take-up and longer intracellular retention than paclitaxel [48]. Due to its pharmacokinetics, the adequacy of paclitaxel is schedule dependent. In general, patterns of predominant reaction rates have been related with higher dosages and delayed infusion rates, yet no routine of paclitaxel has been proved to be measurably better than some other in MBC. Docetaxel is particularly active when given as a short, periodic infusion.

\section{Conclusion:}

The epic details of taxanes do hold some guarantee in disease treatment and may give humble improvement in results. Clearly, there are contrasts between the taxanes, extending from their binding affinity and cell cycle-specific nature to their lethality profiles. Generally the difference in the correlation between agents is uncommon and hard to achieve.

At the present time, clinicians must to pick a taxane-based routine for their patients with breast cancer dependent on the consideration of the pharmacokinetics, clinical activity, and dosing schedule that best addresses the patient's issues. Keeping that in mind, the pharmacokinetic profile, predictable positive clinical outcomes, and convenience of the intermittent, short-infusion schedule support the utilization of docetaxel for some patients with breast cancer at this time.Overall, several adverse effects remained seen with docetaxel than with some of the paclitaxel schedules for particular neutropenia, weakness, and peripheral neuropathy.

Optimizing the dose and schedule of taxane therapy to increase antitumor action while keeping up a safe toxicity profile stays an important objective in metastatic breast cancer (MBC). Weekly, instead of the measure every 3 weeks, dosing regarding docetaxel and paclitaxel at more moderate portions is one approach to give an effective method of drug delivery while managing a favorable toxicity characterization

\section{Acknowledgements:}

We thank Dr.Sreenivas Pasula(,Pharm D (PhD),Department of pharmacy, Bhaskar Pharmacy College) who guided us through this article. we thank A. Srinivas Rao, (principal, Bhaskar Pharmacy College) for providing support, computer laboratory facility, online accessibility of articles and other resources. Finally, we thank the anonymous referees for their useful suggestions.

\section{References:}

[1]: M. Teshome,K. K. Hunt, Neoadjuvanttherapy in the treatment of breast cancer. Surg. Oncol. Clin. N. Am. 23, 505-523 (2014).

[2]: D. Mauri, N. Pavlidis, J. P. A. Ioannidis, Neoadjuvant versus adjuvant systemic treatment in breast cancer: A meta-analysis. J. Natl. Cancer Inst. 97, 188-194 (2005).

[3]: M. Van de Wiel et al., Neoadjuvant systemic therapy in breast cancer: Challenges and uncertainties. Eur. J. Obstet. Gynecol. Reprod. Biol. 210, 144 -156 (2017)

[4]: J.Gralowetal., Preoperative therapy in invasive breast cancer: Pathological assessment and systemic therapy issues in operable disease. J. Clin. Oncol. 26, $814-819$ (2008).

[5]: G. von Minckwitz et al., Definition and impact of pathologic complete response on prognosis after neoadjuvant chemotherapy in various intrinsic breast cancer subtypes. J. Clin. Oncol. 30, 1796-1804 (2012).

[6]: F. Valet et al., Challenging single- and multi-probesets gene expression signatures of pathological complete response to neoadjuvant chemotherapy in breast cancer: Experience of the REMAGUS 02 phase II trial. Breast 22, 1052-1059 (2013).

[7]: Schiff PB, Fant J, Horowitz SB. Promotion of microtubule assembly in vitro by taxol. Nature 1979; 227: 665-667.

[8]: Wani MC, Taylor HL, Wall ME. Plant antitumor agents VI. The isolation and structure of taxol: a novel antileukemic and antitumor agent from Taxus brevifolia. J Am Chem Soc 1971; 93: 2325-2327. 
[9]: Bernstein B. Docetaxel as an alternative to paclitaxel after acute hypersensitivity reactions. Ann Pharmacother 2000; 34: 13321335

[10]: Nuijen B, Bouma M, Schellens JH, Beijnen JH. Progress in the development of alternative pharmaceutical formulations of taxanes. Invest New Drugs 2001; 19: 143-153.

[11]: Jackisch C, Eibach H, Knuth A et al. Phase II trial of docetaxel weekly as dose-dense treatment in metastatic breast cancer (MBC). Proc Am Soc Clin Oncol 2000; 18:417.

[12]: Kim Y, Takatsuka Y, Tanigawara Y et al. Weekly docetaxel for patients with recurrent breast cancer: clinical results and pharmacokinetic/pharmacodynamic assessment. Proc Am Soc Clin Oncol 2000; 18:436a.

[13]: Ford HER, Miles D, Makris A et al. A phase II study of a weekly docetaxel schedule in patients with anthracycline pretreated metastatic breast cancer. Ann Oncol 2002;13(suppl 5):65.

[14]: Ramos M, Gonzalez-Ageitos A, Amenedo M et al. Weekly docetaxel as second-line therapy for patients with advanced breast cancer resistant to previous anthracycline treatment. J Chemother 2003; 15:192-197.

[15]: Mey U, Gorschluter M, Ziske C et al. Weekly docetaxel in patients with pretreated metastatic breast cancer: a phase II trial. Anticancer Drugs 2003; 14:233-238.

[16]: Maisano R, Mare M, Zavattieri M et al. Is weekly docetaxel an active and gentle chemotherapy in the treatment of metastatic breast cancer? Anticancer Res 2003; 23:1923-1926.

[17]: Kuroi K, Bando H, Saji S et al. Protracted administration of weekly docetaxel in metastatic breast cancer. Oncol Rep 2003; 10:1479-1484.

[18]: Burstein HJ, Manola J, Younger J et al. Docetaxel administered on a weekly basis for metastatic breast cancer. J Clin Oncol 2000;18: 1212-1219.

[19]: Stemmler J, Mair W, Stauch M et al. Weekly docetaxel with or without corticosteroid premedication as first or second-line treatment in patients (pts) with metastatic breast cancer (MBC). Proc Am Soc Clin Oncol 2002; 21:58a.

[20]: Aihara T, Kim Y, Takatsuka Y. Phase II study of weekly docetaxel in patients with metastatic breast cancer. Ann Oncol 2002; 13:286-292.

[21]: Hainsworth JD, Burris HA 3rd, Yardley DA et al. Weekly docetaxel in the treatment of elderly patients with advanced breast cancer: a Minnie Pearl Cancer Research Network phase II trial. J Clin Oncol 2001; 19:3500-3505.

[22]: Estevez LG, Cuevas JM, Anton A et al. Weekly docetaxel as neoadjuvant chemotherapy for stage II and III breast cancer: efficacy and correlation with biological markers in a phase II, multicenter study. Clin Cancer Res 2003; 9:686-692.

[23]: D'Hondt R, Paridaens R, Wildiers $\mathrm{H}$ et al. Safety and efficacy of weekly docetaxel in frail and/or elderly patients with metastatic breast cancer

[24]: Ito Y, Aiba K, Horikoshi N et al. Dose-finding phase I study of simultaneous weekly infusion with doxorubicin and docetaxel in patients with advanced breast cancer. Int J Clin Oncol 2001; 6:242-247.

[25]: Wenzel C, Locker GJ, Pluschnig U et al. Phase I/II trial of weekly epidoxorubicin and docetaxel (wED) in the neoadjuvant and palliative treatment of patients with breast cancer. Cancer Chemother Pharmacol 2002; 50:155-159.

[26]: Yardley DA, Whitworth P, Greco FA et al. Neoadjuvant gemcitabine, epirubicin, and docetaxel (GET). Preliminary results from a multi-center phase II trial in inflammatory and locally advanced breast cancer. Breast Cancer Res Treat 2003;82(suppl 1): S54.

[27]: Holmes FA, Blum JL, Kruger S et al. Phase II study of weekly pegylated liposomal doxorubicin and docetaxel as first-line chemotherapy for metastatic breast cancer. Breast Cancer Res Treat 2003;82(suppl 1): S130.

[28]: Brugnatelli S, Danova M, De Bella MT et al. Weekly administration of gemcitabine plus docetaxel in patients with advanced breast cancer: a phase I study. Oncology 2002; 62:3338.

[29]: Frasci G, Comella P, D'Aiuto G et al. Weekly docetaxel plus gemcitabine or vinorelbine in refractory advanced breast cancer patients: a parallel dose-finding study. Southern Italy Cooperative Oncology Group (SICOG). Ann Oncol 2000; 11:367371.
[30]: Fountzilas F, Nicolaides C, Bafaloukos D et al. Docetaxel and gemcitabine in anthracycline-resistant advanced breast cancer: a Hellenic Cooperative Oncology Group phase II study. Cancer Invest 2000; 18:503-509.

[31]: Mavroudis D, Malamos N, Alexopoulos A et al. Salvage chemotherapy in anthracycline-pretreated metastatic breast cancer patients with docetaxel and gemcitabine: a multicenter phase II trial. Greek Breast Cancer Cooperative Group. Ann Oncol 1999; 10:211-215.

[32]: Laufman L, Spiridonidis C, Carman L et al. Second-line chemotherapy with weekly gemcitabine (GEM) and monthly docetaxel (DOC) in patients (pts) with metastatic breast cancer (MBC): a phase II study. Pro Am Soc Clin Oncol 2000; 18:1968a.

[33]: Kornek GV, Ulrich-Pur H, Penz M et al. Treatment of advanced breast cancer with vinorelbine and docetaxel with or without human granulocyte colony-stimulating factor. J Clin Oncol 2001; 19:621-627.

[34]: Esteva FJ, Valero V, Booser D et al. Phase II study of weekly docetaxel and trastuzumab for patients with HER-2overexpressing metastatic breast cancer. J Clin Oncol 2002; 20:1800-1808.

[35]: Soule SE, Miller KD, Porcu P et al. Combined anti-microtubule therapy: a phase II study of weekly docetaxel plus estramustine in patients with metastatic breast cancer. Ann Oncol 2002; 13:1612-1615

[36]: Seidman AD, Hudis CA, Albanel J et al. Dose-dense therapy with weekly 1-hour paclitaxel infusions in the treatment of metastatic breast cancer. J Clin Oncol 1998; 16:3353-3361.

[37]: Wist EA, Sommer HH, Ostenstad B et al. Weekly one-hour paclitaxel as first-line chemotherapy for metastatic breast cancer. Acta Oncol 2004;43:11-14.

[38]: Lombardi D, Crivellari D, Scuderi C et al. Long-term, weekly one-hour infusion of paclitaxel in patients with metastatic breast cancer: a phase II monoinstitutional study. Tumori 2004; 90:285-288.

[39]: Akerley W, Sikov WM, Cummings F et al. Weekly high-dose paclitaxel in metastatic and locally advanced breast cancer: a preliminary report. Semin Oncol 1997;24(suppl 17): S17-87S17-90.

[40]: Perez EA, Vogel CL, Irwin DH et al. Multicenter phase II trial of weekly paclitaxel in women with metastatic breast cancer. J Clin Oncol 2001; 19:4216-4223.

[41]: ten Tije AJ, Smorenburg CH, Seynaeve C et al. Weekly paclitaxel as firstline chemotherapy for elderly patients with metastatic breast cancer. A multicentre phase II trial. Eur J Cancer 2004; 40:352-357.

[42]: Sikov WM, Akerley W, Kahanic S et al. Multicenter, 3-arm randomized study of high-dose weekly paclitaxel (HDWP) versus standard-dose weekly paclitaxel (SWDP) for metastatic breast cancer (MBC). Proc Am Soc Clin Oncol 2002; 21:34a.

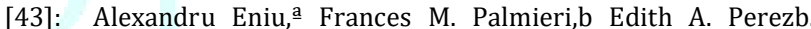
Weekly Administration of Docetaxel and Paclitaxel in Metastatic or Advanced Breast Cancer. The Oncologist 2005; 10:665-685.

[44]:. Haldar S, Basu A, Croce CM. Bcl2 is the guardian of microtubule integrity. Cancer Res 1997; 57:229-233.

[45]: Hennequin C, Giocanti N, Favaudon V. S-phase specificity ofcell killing by docetaxel (Taxotere) in synchronised HeLacells. Br J Cancer 1995; 71:1194-1198.

[46]: Hennequin C, Giocanti N, Favaudon V. S-phase specificity of cell killing by docetaxel (Taxotere) in synchronised HeLa cells. Br J Cancer 1995; 71:1194-1198.

[47]: CancerEst, APHP Tenon, Medical Oncology, Paris, France.Preclinical Pharmacology of the Taxanes: Implications of the Differences the Oncologist 2004;9(suppl 2):3-8

[48]: Burstein HJ, Manola J, Younger J et al. Docetaxel administered on a weekly basis for metastatic breast cancer. J Clin Oncol 2000; 18:1212-1219.

[49]: Riou JF,Petitgenet O,Comneau C et al.Cellular uptake and efflux of docetaxel (Taxotere $\AA$ ) and paclitaxel (Taxol $\AA$ ) in P388 cell line. Proc Am Assoc Cancer Res 1994; 35:385. 